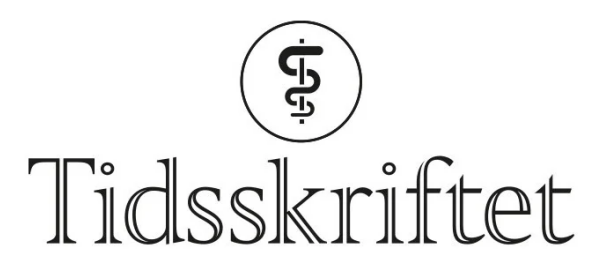

DEN NORSKE LEGEFORENING

\title{
Kan legers utbrenthet påvirke pasientbehandlingen?
}

LEGELIVET

\section{KARIN ISAKSSON RØ}

karin.ro@lefo.no

Karin Isaksson Rø er ph.d. og seniorforsker/lege ved LEFO - Legeforskningsinstituttet.

Leger som opplever arbeidsrelatert stress og utbrenthet, rapporterer selv at lege-pasient-kommunikasjonen påvirkes. Men hvis man bruker observerbare mål, er ikke sammenhengene så tydelige.

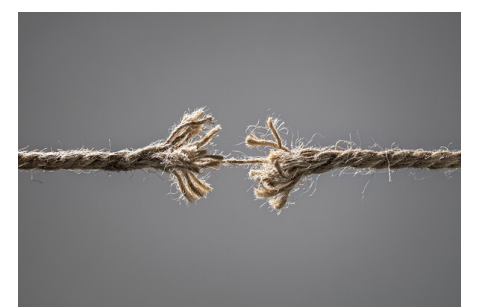

Foto: BrianAJackson/iStock

Flere studier viser en sammenheng mellom en krevende arbeidssituasjon med utvikling av stressrelaterte tilstander og legers opplevelse av mer krevende lege-pasient-relasjon og mindre evne til empati (1). Noen pasienter har rapportert mindre tilfredshet med behandling fra utbrente leger, andre har beskrevet at de opplevde mer empati, mens andre ikke har sett noen sammenheng (2). Vi vet imidlertid lite om relasjonen mellom utbrenthet og observerbare behandlingskonsekvenser. To medisinstudenter i Oslo har derfor gjort en litteraturgjennomgang (3).

Utbrenthet er et resultat av langvarig stress. Den vanligste definisjonen av utbrenthet beskriver en tiltagende følelsesmessig utmattelse, utvikling av emosjonell distansering (der man i mindre grad orker å være empatisk), og etter hvert opplevd redusert kapasitet og effektivitet i eget arbeid (4.). Utvikling av utbrenthet går ofte over lang tid og kan etter hvert utvikles til en utmattelsesdepresjon.

\section{Sprikende funn}


Da man undersøkte om det er forskjeller i behandlingskvalitet gitt av utbrente leger sammenlignet med andre leger, sprikte funnene. I fire studier fant man en sammenheng, mens man i seks studier ikke kunne påviste det (3).

\section{«Det kan vare flere grunner til at man i de fleste studiene ikke ser sammenhenger mellom utbrenthet og observert pasientbehandling»}

Blant de fire studiene med signifikante funn var det to som viste at utbrenthet var forbundet med $ø \mathrm{kt}$ grad av henvisning av pasienter fra primærhelsetjenesten til spesialisthelsetjeneste. I én studie fant man en assosiasjon mellom utbrenthet og økt dødelighet på intensivavdeling, og i én studie at flere pasienter byttet lege hvis allmennpraktikeren var utbrent.

\section{Mulige forklaringer}

Det kan være flere grunner til at man i de fleste studiene ikke ser sammenhenger mellom utbrenthet og observert pasientbehandling. Én viktig forklaring kan være at leger trolig strekker seg langt for å ivareta behandlingskvaliteten, også når de selv opplever stor grad av stress og utbrenthet.

Det er også verdt å merke seg at studiene omfattet kun observerbare forskjeller i behandlingskvalitet. Dette sier ikke noe om viktige deler av pasient-lege-forholdet, slik som pasienttilfredshet eller kvaliteten på kommunikasjonen.

Ved alvorlig utbrenthet/utmattelsesdepresjon er legen kanskje sykmeldt. Sykmeldte leger er ikke inkludert i de aktuelle studiene. Konsekvenser for pasientbehandling som er forårsaket av at legen er sykmeldt og ikke til stede på arbeidsplassen, er dermed ikke blitt undersøkt.

\section{LITTERATUR}

1. Angerer P, Weigl M. Physicians' psychosocial work conditions and quality of care: a literature review. Prof Professionalism 2015; 5: 960. [CrossRef]

2. Rathert C, Williams ES, Linhart H. Evidence for the quadruple aim: a systematic review of the literature on physician burnout and patient outcomes. Med Care 2018; 56: 976-84. [PubMed] [CrossRef]

3. Mangory KY, Ali LY, Rø KI et al. Effect of burnout among physicians on observed adverse patient outcomes: a literature review. BMC Health Serv Res 2021; 21:369. [PubMed][CrossRef]

4. Maslach C, Leiter MP. Understanding burnout: New models. I: C. L. Cooper CL, Quick JC, red. The handbook of stress and health: A guide to research and practice. Hoboken, NJ: Wiley Blackwell, 2017: 36-56.

Publisert: 11. oktober 2021. Tidsskr Nor Legeforen. DOI: 10.4045/tidsskr.21.0667

(C) Tidsskrift for Den norske legeforening 2023. Lastet ned fra tidsskriftet.no 26. april 2023. 